\title{
A TRANSLUCIDEZ DA ANTROPOFAGIA TUPINAMBÁ
}

JARBAS COUTO E LIMA ${ }^{1}$

UFMA

RESUMO: Este artigo analisa as interpretações do canibalismo tubinambá presentes nos registros de viagens franceses e portugueses do século XVI. Correlaciona com tais interpretações aquelas realizadas pelos clássicos da etnologia brasileira. Discute, especialmente, a explicação do canibalismo como vingança ritualizada e como um aspecto essencial da sociabilidade dos ameríndios. Atribui ao pensamento indígena a abertura de novas formas de pensar a subjetividade.

PALAVRAS-CHAVE: canibalismo; tupinambá; subjetividade.

ABSTRACT: This article analyzes the interpretations of Tubinambá cannibalism presented in French and Portuguese travel memoirs from the sixteenth century, correlating such interpretations to those performed by the classics of Brazilian ethnology. It discusses cannibalism as a ritualized revenge and as an essential aspect of the sociability of the Amerindians, highlighting new forms of understanding subjectivity stemmed from indigenous thought.

KEYWORDS: cannibalism; tupinambá; subjectivity.

"Eles falam do tempo" Eduardo Viveiros de Castro (2002, p. 235).

Segundo o historiador Eduardo Bueno (2010), seria uma tarefa de grandes proporções a tentativa de traçar um quadro global da préhistória brasileira. Tanto se a tomássemos no aspecto temporal quanto

\footnotetext{
1 Professor Associado da Universidade Federal do Maranhão com Pós-doutorado pela UNIFESP, Doutorado em Linguística pela Universidade Estadual de Campinas - UNICAMP. Coordenou o Programa de Pós-graduação em Cultura e Sociedade (UFMA). Desenvolveu pesquisa financiada pelo CNPq sobre influências mútuas entre antropologia e psicanálise no modernismo brasileiro. E-mail: jarbasclear@gmail.com.
} 
no espacial. Teríamos que levar em conta 500 séculos (ou 50 mil anos) de existência e uma área de pesquisa que se estenderia da Amazônia ao Pampa e do Nordeste ao Pantanal. Por isso mesmo, antes da década de 60 do século $X X$, pouquíssimos pesquisadores ousaram enveredar por caminhos tão longínquos e idades tão remotas.

O médico naturalista dinamarquês Peter Lund, pesquisador em botânica e zoologia, foi pioneiro em trabalhos arqueológicos no Brasil. Suas descobertas de fósseis humanos em 1840, no estado de Minas Gerais, constituíram um grande avanço para a arqueologia brasileira. Junto aos fósseis daquele que ficaria conhecido como o "homem de Lagoa Santa" (homenagem ao município onde ocorreram as descobertas), foram encontrados ossos de animais, machados, pontas de flecha, furadores e outros instrumentos de pedra lascada, datados de 11 mil anos. Em 1842, Lund publicaria Sobre a Antiguidade do Homem de Lagoa Santa, um tratado a propósito dessas descobertas. Suas memórias seriam organizadas e traduzidas para o português apenas em 1950, pelo paleontólogo Carlos de Paula Couto (1910-1982), sob o título Memórias sobre a Paleontologia Brasileira. Estes talvez sejam os primeiros escritos sobre o período anterior à ocupação pelos europeus da região que chamamos Brasil.

Por outro lado, é possível notar uma velada renúncia à préhistória dos povos indígenas brasileiros. E, consequentemente, de uma alternativa ao ponto de partida comumente adotado para a História do Brasil. Geralmente, definido pela chegada dos europeus em nestas terras já povoadas.

Apontamos esta lacuna historiográfica para situarmos o tempo no discurso antropofágico no Brasil. Tempo referencial da proposição modernista de definir-se excêntrico à história oficial do "descobrimento". Tempo Outro, cuja alteridade se constituirá em referência histórica para as interpretações das crônicas de viagem do século XVI, por parte dos modernistas brasileiros e pela antropologia vindoura. Tempo fundamental no qual repousou a noção de antropofagia em Oswald de Andrade.

Esse enfoque temporal não oficial tornou-se possível desde quando os modernistas brasileiros introduziram uma interpretação propriamente antropofágica do material etnográfico legado pelos 
"viajantes" e missionários do século XVI. Dela brotou a questão levantada neste trabalho: Em que consiste a lógica do tempo da razão antropofágica? Que noção de sujeito inclui?

Durante as tentativas de implantação de estabelecimentos coloniais, sabemos de diversos relatos sobre os povos indígenas brasileiros do século XVI. Produzidos a partir do contato real de "viajantes" e missionários com esses povos, formaram um corpus diversificado e controverso. Relatos que podem ser concebidos ao modo de uma etnografia precoce.

Resumidamente, esse material etnográfico precoce situa-se em dois domínios, o da "literatura informativa" e o da "literatura de viagem", e ainda representa o que há de mais precioso sobre os povos nativos do Brasil no período do "Descobrimento". Com eles e contra eles se construíram e se constroem discursos e silêncios sobre o tema da antropofagia.

Estudos arqueológicos recentes apontam que boa parte do território brasileiro era habitada por homens caçadores e coletores préhistóricos, há, pelos menos, doze milênios (BUENO, 2010). Entretanto, o povoamento da Costa Atlântica brasileira pelos Tupinambá ocorreu apenas nos últimos séculos anteriores à chegada dos invasores europeus (RIBEIRO, 1995).

Falantes $^{2}$ de línguas do mesmo tronco tupi, os Tupinambá formaram grupos sociais diversos por todo território no qual se inventou o Brasil, embora não chegassem a constituir uma nação. Sabese que cada grupo, ao crescer, se bipartia, compondo povos distintos. Ao se diferenciarem, logo se estranhavam e passavam à hostilidade mútua. A tradição de guerra entre os grupos aperfeiçoou nos indivíduos os dotes guerreiros e fez deles os povos dominantes do litoral brasileiro, desalojando antigos ocupantes oriundos de outras matrizes étnicas (RIBEIRO, 1995).

Mas essa tradição guerreira dos Tupinambá só fora interpretada como bravura pelos cronistas europeus enquanto estes eram tributários

\footnotetext{
${ }^{2}$ Não é um exagero reconhecer que os indígenas falavam e ainda falam. Embora, amiúde, negligenciemos o fato de que pensem.
} 
de feitos heroicos ${ }^{3}$ indígenas, na ocasião de alianças de guerra contra invasores concorrentes. Os discursos dominantes posteriores excluíam esse atributo, especialmente do contexto da antropofagia. Tratada como uma prática marginal e horrenda.

A negação da antropofagia como fenômeno integrado à cultura das sociedades ameríndias marca o discurso civilizador do processo de colonização, especialmente na literatura informativa de língua portuguesa. Embora a retórica da antropofagia permaneça recorrente e pujante na literatura de viagem francesa.

As crônicas de religiosos como Jean de Léry, André Thevet, Claude d'Abbeville e Yves d'Evreux trazem à tona, curiosamente, uma relativização do tema da antropofagia. De onde viria o desassombro desses missionários para fazer falar o canibal vivo, guerreiro, agente, sujeito da história?

Para responder a essa pergunta, é preciso levar a sério a presença do tema do canibalismo 4 na literatura francesa. Conforme Frank Lestringant (1997), o desenvolvimento desse tema na literatura francesa é uma tradição que alcançou seu ponto alto no século XVI. A partir daí, sofreu uma degradação progressiva (em paralelo com a destruição cultural e o genocídio dos povos indígenas) até o século XIX. Segundo ele, é possível restabelecer este percurso decadente traçando-se uma linha que vai de Montaigne (século XVI) a Flaubert (século XIX).

Montaigne e Flaubert representam os dois sentidos extremos atribuídos ao canibalismo na literatura francesa. O primeiro sentido extrai-se do próprio encontro de Montaigne com os "canibais" enviados do Brasil e recém-desembarcados na cidade de Rouen 5 , França, em 1562. Naquele momento o canibalismo gozava de grande prestígio na literatura e na filosofia. Esse encontro é um exemplo desse prestígio e

\footnotetext{
${ }^{3}$ Dentre esses heróis está o Tupiniquim Tibiriçá, que "salvou" São Paulo, em 1562, do ataque dos Tamoios, aliados dos franceses; o Temiminó Araribóia, que tomou parte da vitória sobre os franceses em 1567; o Potiguar Felipe Camarão, que ajudou a derrotar os holandeses em 1649 (BUENO, 2010).

${ }^{4}$ Segundo Frank Lestringant, Colombo foi quem recolheu o termo, cuja origem seria a seguinte: "O nome dos canibais deriva originalmente do arawak 'caniba', que seria alteração de 'cariba', palavra pela qual os índios caribes das Pequenas Antilhas se autodesignavam, e que, em sua língua, significaria 'ousado"” (LESTRINGANT, 1997, p. 27).

${ }^{5}$ Rouen é a cidade francesa onde ocorreu, em 1550, a festa em honra do rei Henrique II e da rainha Catarina de Médicis, cujo motivo era a vida dos selvagens no Brasil. Simulando-se uma floresta brasileira, um grupo de 300 pessoas, entre as quais cerca de 50 índios, reencenou hábitos e costumes dos nativos do Brasil, incluindo o ritual antropofágico e a simulação de uma guerra entre duas tribos (ver DENIS, 2007).
} 
da curiosidade que os canibais despertavam no século XVI. O "canibalismo" serve a Montaigne para expressar a má consciência que tem de sua própria sociedade:

Não me pesa acentuar o horror bárbaro que tal acção significa, mas sim que tanto condenemos suas faltas e tão cegos sejamos para as nossas. Penso que há mais barbárie em comer um homem vivo que morto, dilacerar com tormentos e martírios um corpo ainda cheio de vitalidade, assá-lo lentamente e arrojá-lo aos cães e aos porcos, que o mordem e martirizam (como vimos recentemente, e não lemos, entre vizinhos e concidadãos, e não entre antigos inimigos, e, o que é pior, sob pretexto de piedade e de religião) que em o assar e comer depois de morto. Crisipo e Zenon, chefes da seita estóica, opinavam que não havia mal nenhum em nos servirmos dos nossos semelhantes como alimento, se a necessidade a tal nos obrigasse; sitiados nossos antepassados por César na cidade de Alésia, resolveram obviar a fome do assédio com os corpos dos anciãos, mulheres e outras pessoas inúteis para 0 combate (MONTAIGNE, 1978, p. 24).

O segundo sentido do canibalismo na literatura francesa decorre de uma nova visita de "canibais" à Europa, esta em 1853, à mesma cidade de Rouen. Desta vez, Flaubert é quem vistoria os Cafres da África do Sul. Este momento configuraria o "desencontro" que marcaria a decadência do "canibalismo" como tema: "Flaubert não enxerga mais do que uma horda de 'primitivos' cuja visão Ihe suscita um horror quase sagrado. O diálogo com seres tão despossuídos não podia ser mantido" (LESTRINGANT, 1997, p. 12).

A diferença de tratamento do canibalismo e dos canibais nesses dois momentos é apenas uma amostra do que aconteceria, num contexto mais amplo, no âmbito das relações progressivamente degradadas do Ocidente com antropófagos de diversas partes do mundo:

Da idealização heroica do Renascimento ao crepúsculo tempestuoso do romantismo, a degradação da imagem do outro se acompanha, no mesmo período, de uma incompreensão crescente da antropofagia. O modelo de explicação pelo rito, que é o primeiro, é rapidamente substituído, em nome da filosofia e da ciência, por um esquema determinista que remete o uso da matéria à 
tradição do constrangimento natural (LESTRINGANT, 1997, p. 15).

Deslocado do seu contexto original mais favorável ao canibalismo, o espólio da literatura de viagem do século XVI, em especial a de língua francesa, afirma-se, posteriormente, como um corpus privilegiado na construção de um discurso relativizador da alteridade canibal. Reeditando uma tradição que teve em Montaigne seu principal representante, na medida em que o filósofo serve-se, em primeira mão, desses relatos como dados para formular o humanismo de sua filosofia. Presente, inclusive, em sua concepção do canibalismo.

Um quadro afirmativo do canibalismo nos relatos dos missionários pode ser traçado, primeiramente, com André Thevet (1502-1592), em As Singularidades da França Antártica (1978). O autor, um estudioso de cosmografia e cartografia, humanista, frei franciscano, veio ao Brasil como membro da expedição comandada pelo oficial naval Nicolas Durand de Villegagnon. Expedição destacada pelo rei Henrique II na tentativa de fundar a França Antártica, estabelecimento colonial situado na costa sudeste do Brasil. Thevet permanecera em terras brasileiras de novembro de 1555 a janeiro de 1556. Durante sua permanência, coletará muitas informações sobre os indígenas da Baía de Guanabara, local do empreendimento colonial francês. Diversidade e quantidade de dados que conferiram a seu livro o valor documental que ainda possui.

Destacamos desse relato, notadamente, a forma de interpretar a coragem dos "selvagens". De forma muito diferente da "retórica jesuítica" ulterior (LUZ, 2006), Thevet entende a "grande obstinação e coragem" dos Tupinambá em combate. Visto como um "apetite", um "mero apetite de vingança" (THEVET, 1978, p. 127). Esse "apetite de vingança" é adotado como explicação para a eterna inimizade entre os grupos vizinhos tupinambá, e como motivo das guerras sangrentas associadas à prática da antropofagia.

Percebe-se, já nesse autor, que a bravura demonstrada na guerra é aqui descrita e interpretada não como expressão de uma violência animalesca, mas como um processo de interação entre os grupos envolvidos, movidos pelo sentimento mútuo de vingança, em razão de ultrajes recíprocos cometidos contra parentes ancestrais. 
Desse modo, a vingança, a hostilidade mútua, seriam elementos recorrentes na sociedade tupinambá. A guerra, nesse contexto, é vista, antes de tudo, como um jogo que satisfaz o "apetite de vingança" dos grupos envolvidos:

Antes de entrarem em luta aberta [...], postam-se no campo onde travará o combate, afastados do inimigo à distância de um tiro de arcabuz. Durante um certo tempo (às vezes um dia inteiro), ficam trocando injúrias e ameaças, fazendo uns para os outros as mais cruéis e medonhas caretas que podem, ululando e gritando com tal estridor que não conseguiria ouvir o ronco de um trovão. Revelam ainda suas terríveis intenções por meio de gestos, erguendo seus braços e mãos, e exibindo suas clavas e tacapes, enquanto vociferam: 'nós somos valentes! Ontem, devoramos vossos pais; hoje devorar-nos-emos' (THEVET, 1978, p. 127).

Acrescente-se que, por constituir-se numa retaliação mútua e ritual, a vingança tupinambá descrita por Thevet adquire contornos estabelecidos pela distinção natureza/cultura. Isso diferencia a antropofagia tupinambá de uma simples reação instintiva, de natureza puramente animal. A natureza social inerente à vingança torna-se a fronteira para a concepção da antropofagia como uma instituição cultural.

O canibalismo, diz-nos Thevet, é um assunto de vingança, e essa explicação ele imporá à maior parte de seus contemporâneos. Ora, 'vingar-se com todos os dentes', para retomar uma bela expressão que nasceu de sua pena, tem muito pouco a ver com o apetite cego do ogro ou mesmo do lobisomem que devora seu próximo na falta de outro alimento. A expressão aplicase à mastigação de piolhos e de pulgas pelos índios Tupinambás, mas poderia igualmente servir ao consumo, pelos mesmos, de seus inimigos prisioneiros de guerra. Essa atividade oral manifesta um terrível apego a uma extrema impulsividade pouco compatíveis, sem dúvida, com a caridade cristã. Apesar da repugnância que o observador possa ter em relação a tais práticas, que ele qualifica propositadamente de 'bestiais', é forçado a constatar que se trata de atividades humanas, estruturadas numa conduta, irrigadas por um sentido (LESTRINGANT, 1997, p. 8687). 
$\mathrm{Na}$ condição de cosmógrafo, Thevet estabelece esta delimitação entre canibalismo e antropofagia ritual a partir de parâmetros estritamente geográficos. Situa os "canibais" na região que vai do Maranhão até a Bahia de Todos os Santos. E fixa os praticantes da antropofagia ritual 6 na região de Cabo Frio (LESTRINGANT, 1997). A delimitação geográfica de Thevet estabelecia que os indígenas do sul devoravam, exclusivamente, os inimigos, guerreiros aprisionados em guerra ou seus descendentes masculinos. Ao contrário dos ferozes canibais do norte, que não discriminavam suas vítimas. Logo, a demarcação geográfica remete também a uma delimitação conceitual da antropofagia apoiada na presença ou ausência de regras de diferenciação das vítimas preferenciais.

Publicado em 1557, o livro de André Thevet, As Singularidades da França Antártica, foi o substrato etnográfico para o capítulo intitulado Dos canibais, dos Ensaios de Montaigne. A descrição pormenorizada do

\footnotetext{
${ }^{6}$ Em sua descrição, Thevet nos dá o sentido envolvido no ritual canibal: “[...] Os prisioneiros trazidos para a aldeia - cada guerreiro pode trazer quantos quiser, mas geralmente só traz um ou dois - serão ali regiamente tratados. Cinco dias depois de sua chegada, entrega-se ao prisioneiro uma mulher, que pode ser até mesmo a filha daquele que o capturou! Ela está encarregada de prover a todas as suas necessidades, inclusive a de fazer-lhe companhia na rede. Ao mesmo tempo, são-lhes servidos os melhores alimentos que se puderem encontrar. O objetivo é o de engordá-lo qual capão na ceva, até que chegue o dia de matá-lo. [...] Depois que o prisioneiro está devidamente cevado e engordado, matam-no, considerando uma grande honra o ato da execução. E para a solenidade convidam todos os seus amigos [...]. Durante todo o dia e toda noite o condenado entoa canções como esta: 'Meus amigos margajás são pessoas honradas e são hábeis e fortes guerreiros. Eles prenderam e devoraram grande número de inimigos. Agora serei devorado por eles, no dia marcado. Eu, porém, já matei e devorei muitos parentes e amigos do homem que me aprisionou' [...].

[...] No dia solene, todos os assistentes adornam-se com belas plumas de diversas cores, ou pintam o corpo inteiro, especialmente aquele que irá deferir o golpe fatal. Este carrasco deverá estar o mais completamente ataviado que puder, trazendo sua espada de madeira ricamente guarnecida de penas. Quanto maiores forem os preparativos para a sua morte, o mais radiante ficará o condenado. Terminados os preparativos, conduzem-no à praça pública, devidamente amarrado com cordas de algodão, acompanhado de dez ou doze mil selvagens. Ali, executam-no do mesmo modo como se mata um porco: a porretadas. Estas, porém, são precedidas de um longo cerimonial. A mulher que tinha sido dada ao prisioneiro, morto este guardará um luto aliviado.

Logo depois que o matam, os selvagens reduzem o corpo a postas, tomando o cuidado de aparar o sangue. Lavam seus filhos homens neste sangue com o fito de torna-los mais corajosos, conforme pensam, e de mostrar-lhes como deverão proceder com os inimigos quando chegam à idade adulta. É de crer que os seus contrários procedam de maneira idêntica em relação a eles.

Retalhado o corpo e assado à moda indígena, seus pedações serão distribuídos entre tantas pessoas quantas ali se encontrem [...].

([...] O selvagem que executou o prisioneiro, cumprida a sua tarefa, retira-se para sua morada, onde permanece todo dia sem comer nem beber, deitado em sua rede, onde fica durante três dias seguidos sem pôr o pé no chão.[...] depois de um determinado tempo, tomará ele de um instrumento cortante, feito dos dentes de um animal chamado aguti (cutia), e com ele fará diversas incisões e furinhos em vários pontos do corpo [...]". (LESTRINGANT, 1997 p. 131-133).
} 
ritual antropofágico contidas no livro de Thevet permite ao ensaísta francês fazer a crítica de sua própria sociedade:

Tenho em meu poder o canto de um desses prisioneiros. Eis o que diz: 'Que se aproximem todos com coragem e se juntem para comê-lo; em o fazendo comerão seus pais e seus avós que já serviram de alimento a ele próprio e deles seu corpo se constituiu. Estes músculos, esta carne, estas veias, diz-lhes, são vossas, pobres loucos. Não reconheceis a substância dos membros de vossos antepassados que no entanto ainda se encontram em mim? Saboreai-os atentamente, sentireis o gosto de vossa própria carne.' Haverá algo bárbaro nesta composição? (MONTAIGNE, 1987 p. 105).

Montaigne percebe que o "apetite de vingança" dos Tupinambá tem um caráter ancestral. Remete a vingança à memória de uma injúria da qual cada membro do grupo, indiretamente, fora vítima. O ultraje ao parente ancestral, embora sem um caráter pessoal e mesmo real, tornase hegemônico como discurso para manter os grupos irreconciliáveis e diferenciados como tais.

A vingança se apoia, portanto, numa memória transmissível do ultraje, de geração a geração. "Isto é um sentimento que se transmite de pai para filho" (THEVET, 1978, p. 135). O processo de constituição dessa memória não exclui a criança indígena em idade muito tenra. Durante o ritual antropofágico, o costume de passar o sangue do inimigo recémexecutado no bico dos seios das mães revela uma faceta da educação infantil para a vingança.

A memória do grupo social faz parecer aos indivíduos que aquilo que esteve no discurso do grupo desde o início de sua vida individual esteve ali desde sempre. "Como uma desculpa para sua impossibilidade de selarem um acordo honesto, alegam que seus vizinhos e eles têm sido inimigos para todo o sempre..." (THEVET, 1978, p. 127).

O missionário, obviamente, espanta-se com esta impossibilidade de conciliação entre os Tupinambá: "[...] Não se pense jamais em reconciliar um silvícola com alguém que ele julgue tê-lo ultrajado, por menor que seja a ofensa" (THEVET, 1978, p. 135).

Esses relatos e interpretações preliminares da vida dos selvagens brasileiros concebem a guerra e a antropofagia tupinambá assentadas 
num modo especial de sociabilidade. A recorrência desses fenômenos seria uma forma paradoxal de manter a coesão de sua própria sociedade, pela via da agressão mútua. A partir daí, parece possível estabelecer a hipótese de a vingança apoiar uma regra de sociabilidade, a saber: a proibição da reconciliação com os povos vizinhos, com o objetivo de que fosse mantido o exocanibalismo.

Vejamos, entretanto, se os relatos de Thevet que conduziram a essas hipóteses iniciais sobre o canibalismo encontra apoio nos relatos de Jean de Léry, outro importante espólio da "literatura de viagem" do século XVI.

O calvinista Jean de Léry (1534-1613), recrutado por ordem de Villegagnon em Genebra, chegou ao Forte Goligny, na Baía de Guanabara, em princípio de março de 1557 para contribuir na construção de "um refúgio a todos que desejassem fugir às perseguições [da Contrarreforma]" (LÉRY, 2007, p. 54). Jovem, com 21 anos à época, permaneceu no Brasil pelo período de 11 meses. Seu livro Viagem à Terra do Brasil (2007)7, porém, só fora publicado em 1578.

O indígena que Léry delineia é vigoroso e vive até 120 anos sem muitos traços de envelhecimento. Sua descrição ${ }^{8}$ do ritual antropofágico difere daquela de Thevet apenas pela maior nitidez. Sua interpretação do ato antropofágico é, igualmente, ancorada na vingança:

[...] Mas não comem a carne, como poderíamos pensar, por simples gulodice, pois embora confessem ser a carne humana saborosíssima, seu principal intuito é causar temor aos vivos. Move-os a vingança, salvo no que diz respeito às velhas, como já observei. Por isso, para satisfazer o seu sentimento de ódio, devoram tudo

\footnotetext{
${ }^{7} \mathrm{O}$ título original é Histoire d'unvoyagefaictenla terre du Brésil. Sua melhor tradução para o português brasileiro, curiosamente, é a do poeta modernista Sérgio Milliet, que também traduziu os Ensaios de Montaigne. Estamos utilizando a tradução brasileira de Sérgio Milliet.

8 "Não se imagine porém que o prisioneiro com isso se deprima. Ao contrário, com audácia e incrível segurança jacta-se das suas proezas passadas e diz aos que o mantêm amarrado: 'também eu, valente que sou, já amarrei e matei nosso maiores'.

Cada vez mais feroz volta-se para ambos os lados exclamando para uns e outros: 'comi teu pai, matei e moqueei a teus irmãos; comi tantos homens e mulheres, filhos de vós outros tupinambás, a que capturei na guerra, que nem posso dizer-lhes os nomes; e ficai certos de que para vingar a minha morte os maracajás da nação a que pertenço hão de comer ainda tantos de vós quantos possam agarrar'.

[...] Trazem-lhe então pedras e cacos de potes, e os dois guardas receosos de serem feridos, protegem-se com rodelas de couro de tapirassúe dizem-lhe: 'vinga-te antes de morreres'. Começa o prisioneiro a atirar projéteis com todas as suas forças contra os que ali se reúnem em torno dele, algumas vezes em número de três a quatro mil. E é desnecessário dizer que não escolhem suas vítimas" (LÉRY, 2007, p. 194).
} 
do prisioneiro, desde os dedos dos pés até o nariz e cabeça, com exceção, porém, dos miolos, em que não tocam (LÉRY, 2007, p. 103).

A vingança como motor da antropofagia, como se pode ver, não exclui o prazer gustativo pela carne humana. Há, entretanto, na descrição de Léry, um grupo de convivas que se poderia pensar estariam excluídos da lógica da vingança, a saber, as mulheres "velhas". Segundo Léry, sua participação na festa não se justificaria senão pelo prazer9 de comer carne humana: "[...] sobretudo, as velhas, que são mais gulosas da carne humana [...]" (LÉRY, 2007, p. 198).

A "inconstância da alma selvagem" propalada pelos jesuítas, ao atribuírem aos Tupinambá o "atavismo" da antropofagia, a despeito de suas adesões aos princípios da religiosidade cristã, corresponde a uma constância da vingança irreconciliável e ancestral. Essa hipótese preliminar do sentido da antropofagia encontra vários aliados ao longo do pensamento antropológico brasileiro, inclusive na antropologia contemporânea. Viveiros de Castro (2002) argumenta que, entre os Tupinambá, em tudo que diz respeito à vingança, há um sentido, uma constância e uma memória. A vingança estaria no fundamento da vida social dos Tupinambá: "A reprodução do grupo estava, portanto, idealmente vinculada ao dispositivo de preação e execução ritual de inimigos, motor da guerra. Casados, os homens deviam presentear seus sogros e cunhados com cativos, para que estes pudessem vingar-se e ganhar novos nomes" (VIVEIROS DE CASTRO, 2002, p. 228).

Entretanto, uma breve análise dessa questão na fase inaugural da antropologia brasileira é suficiente para apontar a complexidade da questão antropofágica. Pautada numa interpretação mais sistemática das diversas fontes da literatura de viagem e da literatura de informação

\footnotetext{
${ }^{9} \mathrm{O}$ apetite das "velhas" fora do esquema interpretativo da vingança ancestral não parece fazer muito sentido. A demonstração de excesso por parte das anciãs como simples voracidade encobre um motivo muito mais forte. Se considerarmos o vínculo de parentesco como motivação, ao contrário do que pensa Léry, as velhas seriam as mais ávidas de vingança. Com elas a vingança apoiada na ancestralidade da tribo é muito melhor resguardada, mais do que por qualquer outra fração da tribo. Logo, ao expressarem sua "gulodice", expressam também um maior "apetite de vingança". Em função do gênero e da idade, foram também as mais ressentidas do grupo com os ataques sofridos por seus descendentes. Logicamente, tornam-se as principais depositárias desse sentimento de vingança. Visto que tiveram pais, filhos e maridos comidos pelos inimigos que então elas devoravam. A voracidade das "velhas", ao contrário de se tornar uma exceção, explicita a relação entre antropofagia e ancestralidade e com o tempo. Ainda que este aspecto fique um tanto encoberta nas interpretações dos dois autores franceses.
} 
dos séculos XVI e XVII, essa abordagem propriamente antropológica da antropofagia traz à baila um conjunto de novos aspectos do problema. A tese de doutoramento (1947-1951) de Florestan Fernandes, sob a orientação de Roger Bastide, defendida na Universidade de São Paulo (USP), intitulada $A$ função social da guerra na sociedade tupinambá (2006) foi publicada como livro em 1952. Tornou-se a obra-mestra da antropologia brasileira sobre o tema.

Florestan Fernandes enfrentou com maestria e método a investigação de um corpo etnográfico diverso, posto que de segunda mão. Entretanto, aplicou a esse material, minuciosamente analisado, o método de análise comparativa, através do qual pôde realizar uma brilhante interpretação da guerra na sociedade tupinambá, e nesse contexto, da questão da antropofagia. Faremos, a seguir, uma breve exposição dessa interpretação realizada pelo emérito etnólogo e sociólogo brasileiro.

Já no prefácio de $A$ função social da guerra na sociedade tupinambá, Roque de Barros Laraia (2006) ressalta, da interpretação de Florestan, o condão de recusar a compreensão do fenômeno da guerra como resultante de uma agressividade inata da espécie humana. Florestan concebe a guerra como um fenômeno simbólico, portanto, humano. A guerra pressupõe a existência da sociedade. Há guerra porque há sociedade. A agressividade por si não produz guerra, fenômeno simbólico.

No interior deste pensamento, pode-se delimitar uma interpretação da antropofagia tupinambá, segundo a qual, o objetivo do aprisionamento dos inimigos não se relaciona ao aprovisionamento de carne, mas às relações sociais. "Os tupinambá praticavam a antropofagia sob a forma ritual (apesar de alguns cronistas insinuarem o contrário), de modo que a ingestão de carne dos inimigos sacrificados possuía um significado simbólico e mágico" (FERNANDES, 2006, p. 63). Por contraste, o autor nos fará notar ainda esse caráter simbólico no sacrifício ritual e na abstinência da carne de certos animais. A carne da onça sacrificada, por exemplo, não era ingerida.

Segundo Florestan, o principal propósito da guerra era a preação de inimigos para o sacrifício. Estabelece-se aí um vínculo fundamental entre a guerra e a antropofagia. Ambos os fenômenos localizam-se 
num interior de uma ampla rede simbólica cujo motor seria a vingança. Florestan apoia-se na descrição de Gandavo:

É assim a guerra que agora tem uns contra os outros não se levanta na terra por serem diferentes em leis nem em costumes, nem por cobiça alguma de interesses: mas porque antigamente se alguém acertava de matar o outro, como ainda agora algumas vezes acontece (como eles sejam vingativos e vivam como digo absolutamente sem terem superior algum a quem obedeçam nem temam), os parentes do morto se conjuraram contra o matador e sua geração e se perseguiam com tão mortal ódio uns aos outros que daqui veio dividirem-se em diversos bandos, e ficarem inimigos de maneira que agora estão (GANDAVO apud FERNANDES, 2006, p. 66).

Como também observado em Thevet e em Léry, em Gandavo reafirma-se a vingança como principal motivação social da guerra e da antropofagia ritual. Inserida, portanto, nesse contexto vindicativo coletivo.

A "vingança de sangue" como fundamento cultural das guerras tribais, na prática, corresponderia a um amplo processo que ia do demorado ritual de escolha dos inimigos a serem atacados até o ritual antropofágico. Geralmente realizado algum tempo depois do término de combate e já de posse do prisioneiro que seria sacrificado.

Não serve a nossos propósitos reapresentar essa cadeia de acontecimentos reconstituídos amplamente por Florestan Fernandes. Precisa-se apenas circunscrever que o fator biótico alia-se aos planos imaginário e simbólico da vingança.

[...] o motivo aberto das incursões guerreiras contra os grupos locais inimigos circunvizinhos consistia na retaliação. Um fator de ordem religiosa (a crença na necessidade do 'derramamento de sangue com êxito fatal', para vingar os parentes e amigos mortos nas mesmas circunstâncias pelos inimigos), intervinha, pois, igualmente no desencadeamento e na regulamentação social das atividades guerreiras nas áreas ocupadas e sujeitas ao domínio tupinambá. Por isso, acredito ser possível ligar os dois aspectos [biótico e simbólico] conhecidos da função social da guerra na sociedade tupinambá (FERNANDES, 2006, p. 84). 
O aspecto vindicativo da interpretação de Florestan sobre a antropofagia ritual é tão explícito quanto sistemático. O diferencial desta interpretação reside no valor metodológico que caracterizou o trabalho do autor. Dessa forma, uma injúria real recente, ou uma ofensa ancestral imaginária, motivava a guerra, que tinha como fim o aprisionamento do inimigo para o ritual antropofágico. Posto isso, desde a escolha da tribo que seria objeto das incursões guerreiras todo o processo é ritualístico. O ritual antropofágico se encaixa numa rede simbólica que visa à incorporação do inimigo numa elaboração simbólica do desejo de vingança.

Um conjunto de rituais classificados por Florestan como "ritos de tratamento do estranho" demonstram como a vingança é ritualizada como num grande teatro até o seu desfecho, representado pelo ritual antropofágico. Associados ao contexto da expedição de guerra, esses rituais abrangem duas etapas: "a) o aprisionamento dos inimigos e b) a integração transitória dos prisioneiros à vida associativa tribal" (FERNANDES, 2006, p. 100).

Florestan Fernandes destaca o início do processo ritual de incorporação do cativo à vida social da tribo, a partir do rito de aprisionamento ${ }^{10}$, no qual o vencido passa a subordinar-se ao guerreiro, a partir de um gesto simbólico no qual o guerreiro coloca a mão sobre a espádua do cativo. Mas não sem antes livrá-lo de "impurezas" inerentes à sua "personalidade" por sua condição própria de estrangeiro cativo.

Do ponto de vista das relações do tipo captor-cativo e grupo-cativo, a trajetória seguida por eles era bem simples, pois logo se apagavam as vinculações pessoais entre cativo e captor, caindo o primeiro sob o domínio direto e a disposição imediata do grupo. As vinculações pessoais com o captor (ou com a personalidade que 0 substituísse) reatam-se somente depois da atribuição de um status ao cativo na comunidade, e em grande parte como consequência do mesmo (FERNANDES, 2006, p. 102).

\footnotetext{
${ }^{10}$ A descrição do ritual do aprisionamento de inimigos e da integração transitória dos prisioneiros baseiase em relatos produzidos por Evreux e Hans Staden. O segundo descrevendo seu próprio aprisionamento.
} 
Florestan Fernandes organiza os momentos capitais daqueles fenômenos classificados por ele de "ritos de tratamento do estranho". Iniciam-se com a "recepção agressiva". Esse momento constitui-se na chegada do prisioneiro à região da tribo. Nesse local, em geral, uma praia, um grande número de membros da tribo esperavam. Ao recebêlo, esses membros o ameaçavam com pantomimas, mordendo seus próprios braços, enquanto outros o agrediam com socos. Os zombamentos e ameaças seguiam na chegada ao acampamento. Depois de levado à maloca do captor onde recebia uma rede onde deveria, mulheres e crianças tinham também a oportunidade de atitudes agressivas contra o prisioneiro.

$\mathrm{Na}$ interpretação do autor, essas agressões demonstram que a aceitação do estranho associava-se ao desejo e à necessidade de vingança, "servindo os parentes e amigos mortos pelo adversário no 'leito de honra' como penhor das relações estabelecidas entre as personalidades hostis em presença (os captores e os cativos)" (FERNANDES, 2006, p. 103). Podemos deduzir dessa interpretação dos ritos de recepção agressiva que eles representavam uma forma de elaboração psíquica, através de gestos simbólicos, das "emoções recalcadas" de vingança. Em seguida dão-se os "ritos de preparação agressiva do prisioneiro". Esses ritos eram realizados no dia seguinte à recepção agressiva e constituíam-se em cuidados corporais do cativo realizados com exaltação e vivacidade pelas mulheres da tribo do captor. Desenrolava-se, em geral, num processo de depilação e ornamentação com penas. Ao que se seguiam os "ritos de renovação da sepultura", nos quais o prisioneiro era conduzido à maloca do defunto que deveria ser vingado, cuja sepultura era então renovada pelo cativo. "Nessa ocasião punham diante dele a rede, o arco, as flechas, os ornamentos e outros objetos pertencentes ao morto para que deles se servisse o cativo enquanto vivesse" (FERNANDES, 2006, p. 107).

Com o ritual de renovação da sepultura do defunto vingado são limpos e purificados os objetos pessoais do morto, através de uso pelo inimigo capturado. Permite-se, assim, o uso desses utensílios pelos membros da tribo local.

Segundo Florestan Fernandes, esses dois momentos capitais dos "ritos de tratamento do estranho", ao mesmo tempo em que concluíam 
o processo de integração do prisioneiro ao grupo do captor, implicavam em "modificações na personalidade" do prisioneiro. Tais modificações o preparavam para uma próxima etapa que culminaria na transferência da posse do prisioneiro, da comunidade para o captor ou seu substituto. Depois de algum tempo morando na maloca do captor, celebrava-se o ritual antropofágico (já descrito neste trabalho), concebido pelo autor como um sacrifício à memória do membro da tribo morto.

Do ponto de vista metodológico, a principal diferença entre a clássica interpretação de Florestan Fernandes e a que passaremos a abordar, realizada por Eduardo Viveiros de Castro em Araweté: os deuses canibais (1986), reside no fato de que Viveiros de Castro pesquisou uma um povo tupinambá vivo. Ou seja, fez a etnografia dos Araweté, povo de língua tupi-guarani da Amazônia Oriental, nos moldes clássicos. O foco deste premiado trabalho é a descrição e interpretação da cosmologia desse povo, na qual os conceitos araweté de pessoa e divindade desempenham papel significativo e o tema do "canibalismo divino", por sua vez, torna-se central para compreendê-los.

Esse caso particular de canibalismo chamado "divino" relaciona-se ao relato dos Araweté de que "as almas dos seus mortos, uma vez chegadas ao céu, são mortas e devoradas pelos Mâî, os deuses, que em seguida as ressuscitam, a partir dos ossos; elas, então, se tornam como deuses imortais." (VIVEIROS DE CASTRO, 1986, p. 22). Segundo Viveiros de Castro, o canibalismo divino condensa a noção araweté de pessoa assim descrita: "o destino da Pessoa Araweté é um tornar-se outro , e isso é a pessoa - um devir. Intervalo tenso, ela não existe fora do movimento" (VIVEIROS DE CASTRO, 1986, p. 22).

O autor propõe mesmo a hipótese de um "método tupi-guarani de des-construção da Pessoa", de tendência "não euclidiana". Um método que recusa o ciclo vicioso da especularidade da identificação narcísica para afirmar um "processo de deformação topológica contínua, onde Eu e Outro, Ego e Inimigo, o vivo e o morto, o homem e o deus, o devorado e o devorador, estão entrelaçados - aquém e além da Representação, da substituição metafórica, e da oposição complementar. Movendo-se em um universo onde o devir é anterior ao Ser, e a ele insubmisso" (VIVEIROS DE CASTRO, 1986, p. 22). Observemos, nessa concepção de Pessoa araweté, o morto como alteridade, o que destaca-se por uma 
relação temporal diversa daquela presente na interpretação do canibalismo tupinambá feita por Florestan Fernandes. Lá o canibalismo visava a vingança do morto. A relação com esse outro morto dá-se numa referência ao passado. Ao passo que na relação com o morto no canibalismo divino araweté a referência é o futuro, o devir.

Uma particular forma de deslocamento da posição do sujeito do discurso compõe a cosmologia araweté. Não à toa esse plano reflete uma forma "antinarcísica" de lidar com a alteridade. Entre os Araweté prevalece um estilo de discurso "citado", onde é mais apropriado ou mais confortável

falar do que disse o outro, abolir-se como fonte primeira do discurso, impedir a coincidência entre o sujeito do enunciado e o sujeito da enunciação. Tudo se passa como se a palavra Araweté fosse sempre a palavra de um outro (VIVEIROS DE CASTRO, 1986, p.64-65).

Em Viveiros de Castro a noção de devir associa-se a um esvaziamento da noção de sujeito como autoidentificado. Nas palavras do autor, o termo indica uma dissociação do campo da noção de Pessoa e do campo da Identidade e do Ser como identidade-a-si:

emprego o conceito para indicar que o ser da pessoa Araweté é um devir-outro, devir-deus, - inimigo, jaguar, onde se o Outro, enquanto objeto do Devir, é imaginário, o devir é real, e a alteridade uma qualidade do verbo, não um predicado seu (VIVEIROS DE CASTRO, 1986, p. 124).

Para desenvolver a noção de "devir-outro", Viveiros de Castro comenta a clássica passagem do livro Hans Staden, Viagem ao Brasil, de 1557:

No dia seguinte, estávamos não longe da sua terra, ao pé de uma grande montanha, denominada Occarasu. Ahi acamparam para passar a noite. Fui então à cabana do chefe principal (Konian Bebe chamado) e the perguntei o que tencionava fazer com os mammelucos. Disse-me que seriam devorados e me prohibiu de lhes falar, pois que estava muito zangado com elles; deviam ter ficado em casa e não irem com seus inimigos em guerra contra elle. Pedi-Ihe que os deixasse viver e os 
vendesse aos seus amigos, outra vez. Tornou a dizerme que seriam devorados.

E esse mesmo Konian Bebe tinha uma grande cesta cheia de carne humana diante de si e estava a comer uma perna, que elle fez chegar perto de minha bocca, perguntando se eu também queria comer. Respondi que sómente um animal irracional devora a outro, como podia então um homem devorar a outro homem? Cravou então os dentes na carne e disse: 'Jau ware sche' que quer dizer: 'Sou uma onça, está gostoso!' Com isto, retirei-me de sua presença (STADEN,1988, p. 132).

Viveiros de Castro interpreta a cena citada acima como um exemplo do devir tupinambá. O guerreiro aponta em seu discurso aquilo através do que ele se vê, ou seja, um jaguar. Um guerreiro tupinambá comendo um homem é a perspectiva de um jaguar (animal cuja carne era proibida de ser comida, como já destacado por Florestan Fernandes). Entenda-se, portanto, o ato como perspectiva e não como metáfora, substituição significante. Perspectiva em seu sentido etimológico mesmo, do latim perspicere (ver através de). Ou como uma substituição metafórica bastante literal, em que a perspectiva substitui o objeto refletido num meio translúcido. Um virar-jaguar que depende mais da posição do objeto e da natureza translúcida do aparato, do que das qualidades inerentes ao próprio objeto. Tudo isso, sem dúvida delineado pelo discurso, pela fala do guerreiro.

Um livro bem mais recente de Viveiros de Castro, intitulado Metafísicas Canibais (2015), compõe um conjunto de reflexões amadurecidas na longa e fascinante carreira antropológica de Eduardo Viveiros de Castro. Segundo o próprio autor, esse escrito tem o estatuto de uma resenha. Resenha de $O$ Anti-Narciso, um livro-devir que funciona para Metafísicas Canibais como funciona um jaguar para um guerreiro tupinambá. O livro é deslocado do seu lugar próprio, numa manobra literária, para tornar-se um narciso visto através de um meio translúcido de uma teoria multiautoral. A concepção de "metafísicas canibais" é semelhante a um desenho em perspectiva. Mas o conceito de perspectivismo ameríndio presente na forma do livro é também central em seu conteúdo.

A primeira vertente desse perspectivismo é inspirada na "metafísica da predação" de Lévi-Strauss e revela a transformação 
estrutural dos conceitos indígenas pela filosofia contemporânea. A segunda, no próprio compromisso com o devir de mundos possíveis da filosofia deleuziana. Entretanto, sente-se aí também a presença indelével de Oswald de Andrade, pioneiro em estabelecer a conexão "inimista" entre a filosofia do por vir e os conceitos indígenas. Assim também como na cosmologia ameríndia, a alma é um atributo imanente a todas as coisas; o corpo, ao contrário, é um devir, em construção permanente na relação com seres e coisas.

A noção de perspectivismo desenvolvida em Metafísicas Canibais, apoiada no pensamento ameríndio e na estrutura diferencial própria do mito, pressupõe uma identidade virtual de fundo entre eu e Outro, entre humanos e não humanos, a partir da qual podem ser vistos e afirmados em suas diferenças. Desta forma a própria diferença (humano/não humano) é trazida para o interior de cada existente, humano ou não humano. Num sentido em que a diferença entre os pontos de vista é, ao mesmo tempo, "anulada e exacerbada". Numa passagem, o autor afirma: "Essa parece-me ser, em última análise a ideia de alma nas antologias indígenas. Se todos os seres têm alma, nenhum deles, ninguém, coincide consigo mesmo" (VIVEIROS DE CASTRO, 2015, p. 62).

Onde, então, se construiriam as diferenças sob esse fundo virtual anímico dos seres? A resposta é reduzida, mas complexa: no corpo. As diferenças entre os pontos de vista não estariam na alma, mas no corpo, "como um conjunto de maneiras ou modos de ser que constituem um habitus, um ethos, um ethograma (o que come, como se move, onde vive, se é gregário ou solitário, tímido ou agressivo)" (VIVEIROS DE CASTRO, 2015, p. 66). Assim como no estruturalismo, o pensamento ameríndio consistiria num processo de transformação, de tradução do ser do outro. Num processo de comunicação equívoco que se dá pela diferença. "É comunicar pela diferença, em vez de silenciar o Outro ao presumir uma univocidade originária e uma redundância última - uma semelhança essencial - entre o que eles e nós estávamos dizendo" (VIVEIROS DE CASTRO, 2015, p. 91).

Em duas passagens fundamentais de $O$ Anti-Narciso, citações de O totemismo hoje e de $O$ pensamento selvagem, Eduardo Viveiros de Castro localiza um "contraste paradigmático" estabelecido por LéviStrauss entre "totemismo" e "sacrifício", a partir do qual distingue o 
"canibalismo místico-funerário" das culturas andinas e mesoamericanas do "canibalismo bélico sociológico", próprio dos Tupinambá. A distinção entre essas duas formas de predação estaria em que a predação tupinambá implicaria a questão da afinidade e da identificação com o inimigo, não com entidades sobrenaturais. Uma vez que, no ritual antropofágico, o oficiante executor do cativo, que será beneficiado com direitos sociais na tribo, se entregava a um processo de identificação com o inimigo a quem acabara de executar, como vimos em Florestan. Porém, Viveiros de Castro diferencia sua interpretação do canibalismo daquela realizada por Florestan Fernandes em $A$ função social da guerra na sociedade Tupinambá, para quem "o sacrifício se dirigia aos espíritos dos mortos do grupo, vingados e celebrados pela execução do cativo na guerra" (FERNANDES, 2006, p. 158).

O autor de Metafísicas Canibais contesta a ideia de entidades sobrenaturais envolvidas no canibalismo tupinambá. Sua abordagem de cunho estruturalista estabelece uma analogia entre o canibalismo funerário araweté e o canibalismo sociológico tupi, assim descrita:

os mai araweté (as divindades) ocupavam o lugar que, no rito tupinambá, era ocupado pelo grupo em função do sujeito - o grupo do matador e seus aliados, que devorava o cativo -, ao passo que o lugar do objeto do sacrifício, o cativo do rito tupinambá, era ocupado pelos mortos araweté. Os viventes araweté, por fim, ocupavam o lugar do co-sujeito que, nos Tupinambá, era ocupado pelo grupo inimigo, aquele de onde a vítima era extraída. A transformação, em suma, que o canibalismo divino araweté efetuava sobre 0 canibalismo humano tupinambá não dizia respeito ao conteúdo simbólico dessa prática ou a sua função social, mas a um deslocamento pragmático, uma torção uma translação de perspectiva que afetava os valores e as funções de 'sujeito' e 'objeto', de 'meio' e de 'fim', de 'si' e de 'outrem' (VIVEIROS DE CASTRO, 2015, p. 159).

Esse movimento de "torção" ou "translação" de perspectiva indicaria uma propriedade da antropofagia araweté. Uma estrutura definida como processo de transmutação de perspectivas que compreende o movimento assim descrito: "O 'eu' se determina como 'outro' pelo ato mesmo de incorporar este outro, que por sua vez se 
torna um 'eu', mas sempre no outro, através do outro ('através' também no sentido solecístico de 'por meio de') (VIVEIROS DE CASTRO, 2015, p. 159).

Aplicando esse esquema à antropofagia tupinambá, Viveiros de Castro responde a uma questão crucial da relação eu/Outro: o que do inimigo é devorado, precisamente?

a relação do inimigo com o devorador, sua condição de inimigo. O que se assimilava da vítima eram os signos de sua alteridade, e o que se visava era essa alteridade como ponto de vista sobre o Eu [...] autodeterminação recíproca pelo ponto de vista do inimigo (VIVEIROS DE CASTRO, 2015, p. 159-160).

Metafísicas Canibais revela, assim, um outro sentido da vingança, como modelo de sociabilidade baseada num tipo de "economia da alteridade predatória", cuja "interioridade do corpo social é integralmente constituída pela captura de recursos simbólicos - nomes e almas, pessoas e troféus, palavras e memórias - do exterior. [...] uma sociedade sem interior que não é senão fora de si" (VIVEIROS DE CASTRO, 2015, p. 161-162). A economia da predação corresponde, assim, a um modelo que projeta um mundo baseado numa "ficção antropológica", da qual se deve extrair consequências para a experiência, na construção de um mundo por vir. Trata-se, segundo Viveiros de Castro, menos de uma interpretação do pensamento ameríndio do que de realizar uma experiência com esse pensamento. Experiência presente na própria escrita do livro Metafísicas Canibais. Ao concebê-lo como uma resenha de um livro imaginário, o autor vincula a existência de Metafísicas Canibais à exterioridade perspectiva de $O$ Anti-Narciso. Realiza, assim, uma experiência literária a partir de pressupostos intelectuais gerados nas entranhas dos povos ágrafos amazônicos. Permite retomada da questão antropofágica como instrumento adequado ao pensamento sobre a questão da subjetividade. Assim como Oswald de Andrade encontrou em Freud e em Hegel: "O homem absorvido pelo objeto que ele contempla só pode voltar a si por um desejo: pelo desejo de comer, por exemplo".

Oswald define antropofagia como "transfiguração": "Tínhamos [na sociedade antiga tupinambá] a justiça codificada da vingança. A ciência 
codificada da Magia. Antropofagia. A transformação permanente do Tabu em totem" (ANDRADE, 2011 , p. 69).

Encontramos aí dois aspectos bastante perturbadores. $\mathrm{O}$ primeiro é a inversão da lei do mito de transfiguração do totem em tabu em lei da vingança. Para explicar essa operação, numa conferência realizada em 1945, em São Paulo, Oswald se apoia na dialética hegeliana. Referese ao aspecto dinâmico e contraditório da antropofagia concebida como Weltanschauung (cosmovisão ou visão de mundo). No interior dessa cosmovisão de inspiração tupinambá, a antropofagia se situa como "comunhão do valor adverso".

O processo antropofágico concebido como uma dialética da visão de mundo é um desmonte dialético da relação identitária positivista. $\mathrm{O}$ outro, enquanto inimigo, afirmado em seu valor e assimilado em sua diferença.

Importante destacar que a concepção da operação de "transfiguração" está apoiada, principalmente, em Freud. A lógica da transformação do totem em tabu, retirada da teoria do mito, é crucial para a articulação entre totemismo e tabu do incesto - contribuição original de Freud à antropologia de sua época.

$\mathrm{Na}$ medida em que a antropofagia oswaldiana, concebida como estrutura subjetiva, apoia-se na noção de "transfiguração", podemos supor esta subversão da relação identitária positivista como homóloga àquela presente no conceito de "translação de perspectiva" em Eduardo Viveiros de Castro, tomado como dupla torção, política e epistemológica. Do ponto de vista epistemológico, tem ele tem o condão de atualizar as relações do eu ao Outro, numa perspectiva não determinista. Ou seja, numa concepção em que o eu e o Outro se superpõem de forma "indecidível", ou seja, nem o eu determina o Outro nem o Outo determina o eu, mas ambos se influenciam mutuamente. A noção de perspectivismo desenvolvida em Metafísicas Canibais, apoiada no pensamento ameríndio e na estrutura diferencial própria do mito, pressupõe uma identidade virtual de fundo entre eu e Outro, entre humanos e não humanos, a partir da qual os seres podem ser vistos e afirmados em suas diferenças. Desta forma a própria diferença (humano/não humano) é trazida para o interior de cada existente, humano ou não humano. Nesse sentido, a diferença entre os pontos de 
vista é, ao mesmo tempo, "anulada e exacerbada", no que se transforma noutra forma de consciência do outro, implicada numa concepção muito mais ampla de humanidade. A antropofagia tupinambá apoia-se, portanto, numa forma de sociabilidade e numa forma de subjetividade que poderíamos denominar translúcidas.

\section{Referências bibliográficas}

ANDRADE, Oswald. A Utopia Antropofágica. São Paulo: Globo, 2011. (Obras Completas de Oswald de Andrade).

BUENO, Eduardo. Brasil: uma história: cinco séculos de um país em construção. São Paulo: Leya, 2010.

DENIS, Ferdinand. Uma festa brasileira celebrada em Rouen em 1550: teogonia dos antigos povos do Brasil, um fragmento do século XV. São Bernardo do Campo: Bazar das Palavras, 2007.

FERNANDES, Florestan. A função social da guerra na sociedade tupinambá. São Paulo: Editora Globo, 2006.

FREUD, Sigmund. Totem e Tabu. In: . Freud: edição standard brasileira das obras psicológicas completas de Sigmund Freud. Rio de Janeiro: Imago, 1987. v. 13, p.111-191.

LARAIA, Roque De Barros. Cultura um conceito Antropológico. Rio de Janeiro: Jorge Zahar, 2006.

LÉRY, Jean de. Viagem à Terra do Brasil. Belo Horizonte: Ed. Itatiaia; São Paulo: Ed. da Universidade de São Paulo, 2007.

LESTRINGANT, Frank. O Canibal: grandeza e decadência. Brasília: Editora Universidade de Brasília, 1997.

LÉVI-STRAUSS, Claude. As Estruturas Elementares do Parentesco. Petrópolis: Vozes, 1982.

LIMA, JARBAS C. Uma Antropofagia da Interpretação: a transmissão da psicanálise com o modernismo no Brasil. In: LEITE, Nina Virgínia de Araújo, VORCARO, Angela (Org.). Giros da Transmissão em Psicanálise: instituição, clínica e arte. Campinas: Mercado de Letras, 2009. p. 297-308. 
LUND, Peter Wilhelm. Sobre a Antiguidade do Homem de Lagoa Santa. Rio de Janeiro: Instituto Geográfico Brasileiro, 1842.

- Memórias Sobre a Paleontologia Brasileira. Rio de Janeiro: Instituto Nacional Do Livro, 1950.

LUZ, Amaral Guilherme. Carne Humana: canibalismo e retórica jesuítica na América portuguesa (1549 -1587). Uberlândia: Edufo, 2006.

MONTAIGNE, Michel de. Ensaios. São Paulo: Nova Cultural, 1987.

RIBEIRO, Darcy. O Povo Brasileiro: a formação e o sentido do Brasil. São Paulo: Companhia das Letras, 1995.

STADEN, Hans. Viagens e aventuras no Brasil. São Paulo: Melhoramentos, 1988.

THEVET, André. As Singularidades da França Antártica. Belo Horizonte: Ed. Itatiaia; São Paulo: Ed da Universidade de São Paulo, 1978.

VIVEIROS DE CASTRO, Eduardo. Arawete: os deuses canibais. Rio de Janeiro: Jorge Zahar, 1986.

A Inconstância da Alma Selvagem. São Paulo: Cosac\&Naify, 2002.

Metafísicas canibais: elementos para uma antropologia estrutural. São Paulo: Cosac Naify, 2015.

Recebido em: 12/07/2016 * Aprovado em: 21/06/2017 * Publicado em: 30/06/2017 